\title{
Powder Injection Moulding Technology: Properties, Possibilities and Starting Activities
}

\author{
Jovan Radulović ${ }^{1)}$
}

\begin{abstract}
Powder Injection Moulding (shortly PIM) enables a high-volume production of completely metal or ceramic complex geometry parts starting from non-completely metallic and ceramic materials, frequently plastic feedstock.

Four phases of the PIM technology are described (compounding of feedstock, injection moulding of plastic binder/metal powder, debinding of binder component and sintering) based on the material consisting of thermoplastic binder and metal powder. A feedstock polyacetal binder/low alloy steel powder was chosen and by injection moulding technology the injection molded product, called a "green part", is obtained. By this way, the "green part" (precisely, test specimen according to the ASTM E8/E8M-11 standard) is produced in Serbia for the first time. A feedstock characteristics (density, semi-quantitative analysis and visual appearance) and "green part "properties (mass, density, semi-quantitative analysis and visual appearance) were tested. It was concluded that satisfactory results were obtained.
\end{abstract}

Key words: injection moulding, powder moulding, technological improvements, process properties.

\section{Introduction}

$\mathrm{S}$ GNIFICANT technical and technological progress in almost all areas of human activities resulted in investigation, development and production of the whole spectrum of different new materials [1].

One of the new technologies which enable a high-volume production of complex geometry parts is the Powder Injection Moulding (shortly PIM) [2].

PIM technology was first used in the 1930s for injection moulding ceramic sheaths to mass produce the spark plug insulators. The process was adopted by the investment casting industry in which it is still used for manufacturing the ceramic cores. However, the PIM attracted a little different interest until it was used for the moulding of metal powders in the mid 1970s. This novel application initiated considerable worldwide research in the following years. The research strengthened the science and knowledge base of the PIM, and it is now recognized as a sophisticated, interdisciplinary technology [3].

An early developer of the process during the 1970s was Dr. Raymond E. Wiech Jr., who refined the MIM technology, and later patented this process, widely adopted for manufacturing use in the 1980s [4,5].

\section{Powder Injection Moulding technology -PIM- technology}

Powder injection moulding (PIM) technology allows metal or ceramic parts production with the same ease and design freedom as for the plastics material.

PIM technology can consist of four main phases:

1. compounding i.e. preparing of feedstock,

2. injection moulding,
3. debinding and

4. sintering.

There is a particular science associated with each stage of the process, which is shown in Fig.1.

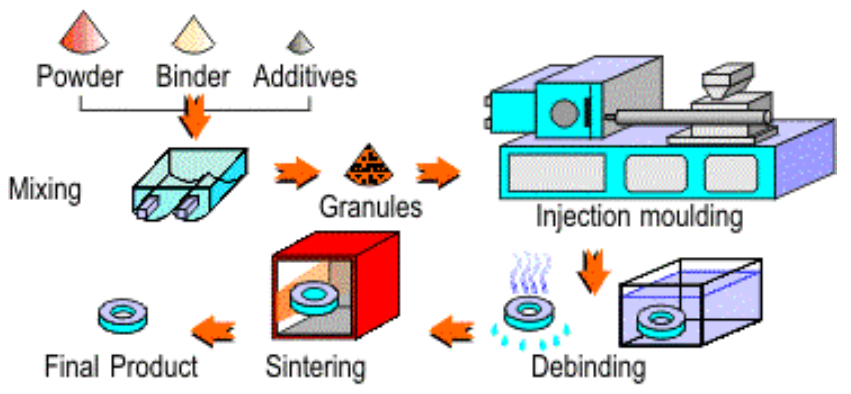

Figure 1. The powder injection moulding process

\section{Preparing of the feedstock}

Feedstock or, more precisely speaking, a starting material for the injection moulding process consists of the binder and powder.

It is essential that the binder must be able to incorporate a high volume of fine metal or ceramic powders (typically $60 \%$ by volume), to form a coherent mass that can be plastified and injection moulded at the elevated temperature, to allow removal of the main binder constituent in a reasonably short, environmentally friendly process and to provide enough strength after debinding by means of the "backbone binder" [6].

A role of binder is to adhere a powder particles and to enable their production by injection moulding technology and to give a resistance of the product during all phases of the PIM process. A combination of two binders (one as the main and the other as a secondary) gives the best results: the main

\footnotetext{
1) Military Technical Institute (VTI), Ratka Resanovića 1, 11132 Belgrade, SERBIA

Correspondence to: Jovan Radulović; e-mail: jovan.r.radulovic@gmail.com
} 
binder is removed almost completely during debinded phase and the residual one ("backbone") gives strength to the PIM shaped samples after debinding and is removed in sintering phase. Binders most often used are thermoplastic materials (POM-polyoxymethylene ie. polyacetals, PE-polyethylene, PS-polystyrene, PPS-polyphenylene sulphide), PW-paraffin wax, PEG-polyethylene glycol, MW-microcrystalline wax, thermoreactive resins, water-based systems (agar, carrageenan), elastomers (EVA), etc. Beside the main and secondary binders, another additives are used (lubricants, surface active agents to lower viscosity and improve impregnating, hardeners, etc) $[7,8]$.

Powders should have tailored particle size distribution, for a high packing density and low cost (mixture of the lower cost large particles and higher cost small particles), no agglomeration, predominantly spherical (or at least equiaxed) particle shape, smooth surfaces for a better flow of the feedstock, sufficient inter-particle adhesion to avoid the distortion after binder removal, small mean particle size for a rapid sintering $(<20 \mu \mathrm{m})$, dense particles free of internal voids, minimized explosion and toxic hazards and clean particle surface for the predictable impregnation with the binder. The list of the powders that have been used includes stainless, low alloy and high speed steels; copper, nickel, aluminium and cobalt base alloys; carbides, titanium, magnetic alloys, refractory and hard metals; ceramic materials (alumine, circonate, silicone-carbide, silicone-nitride), metal matrix composites (MMC), ceramic matrix composites (CMC), etc. [8].

The maximum level of the solids that can be used, above which the material loses reasonable flow properties, is determined by the physical-chemical characteristics of the particulates and binder system. In general, increasing the volume fraction of the spherical particles above 0,4 has an adverse effect on rheology, as shown in Fig.2.

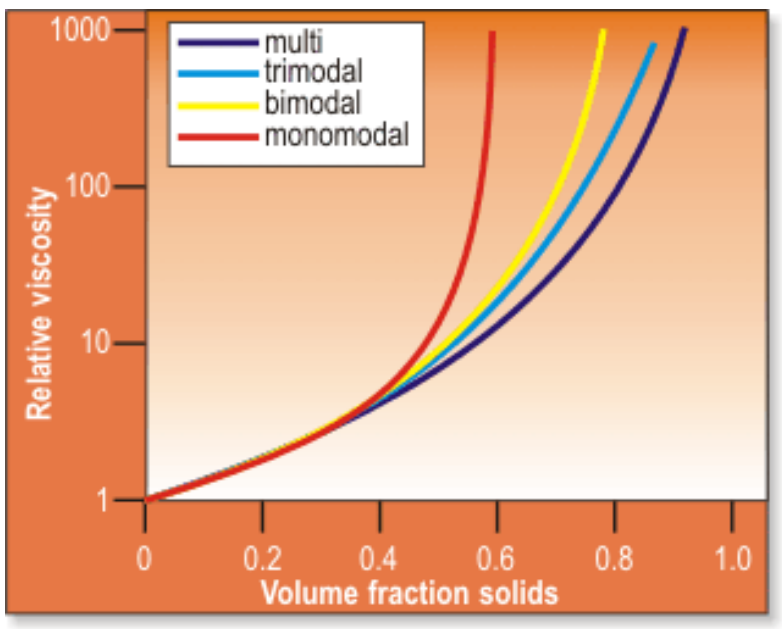

Figure 2. Effect of a particle volume fraction on the composition viscosity

The relative viscosity is the ratio of the viscosity of the filled system to the viscosity of the base binder system.

The high viscosity of polyacetal limits the particle volume fraction to no more than 0,6 .

\section{Injection moulding}

When the Hyatt brothers, John and Isaiah, built and patented the first injection moulding machine in 1872, it was doubtful if they could possibly have imagined the impact this invention would have on the world [9].

Geometrically complex parts can be economically manufactured with the conventional injection moulding machines using thermoplastic materials with metal or ceramic powder [10].

The injection moulding cycle can be split in the following steps [11]:

1. Close of the mould: empty mould is closed while the quantity of plasticized material inside the barrel is ready to inject (Figure 3).

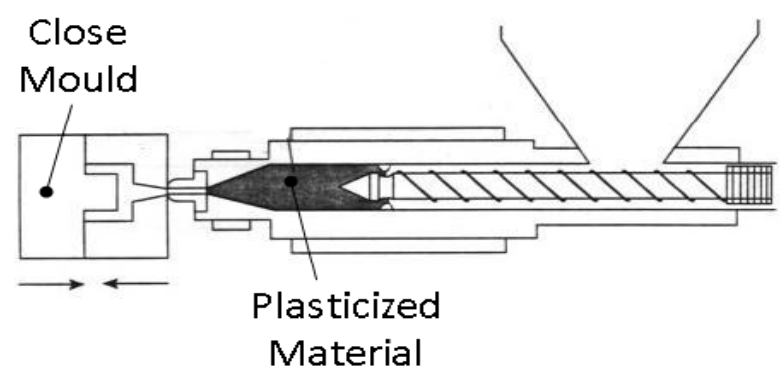

Figure 3. Close of the mould

2. Injection of material: a screw injects the plasticized and molten material, pushing it through the nozzle inside the mould cavities with injection pressure (Figure 4).

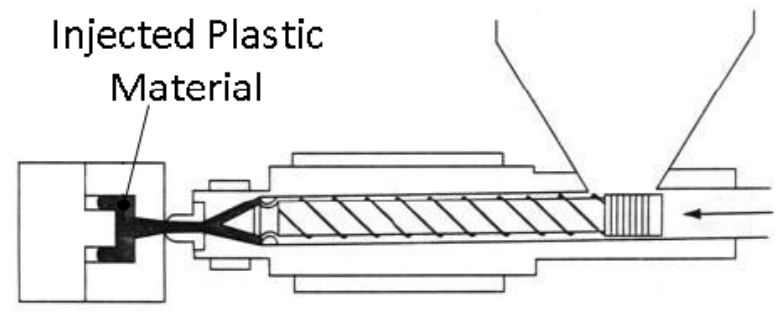

Figure 4. Material injection

3. Maintenance of the additional pressure: when the plastic material is injected, the screw is kept in front, applying the pressure before it is solidified, to minimize the part shrinkage during cooling. Maintenance pressure is usually smaller than the injection pressure and it is supported until the part starts to solidify (Fig.5).

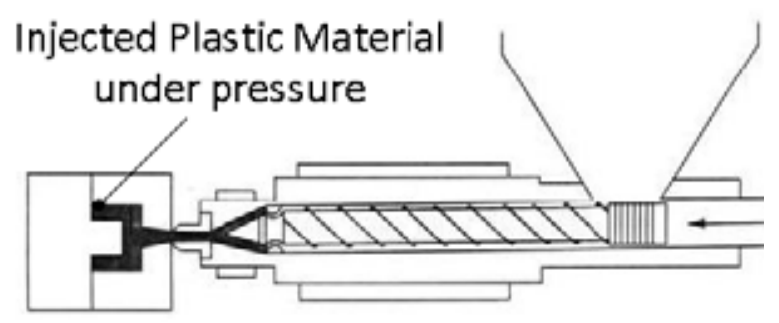

Figure 5. Maintenance Pressure

4. Plasticization of material: a screw turns passing the plastic grains since the hopper and it plasticizes them. Fund material is supplied through the front part of the screw, where it developed a pressure against the closed nozzle, forcing the screw to go back until it finds the required material for the injection (Fig.6).

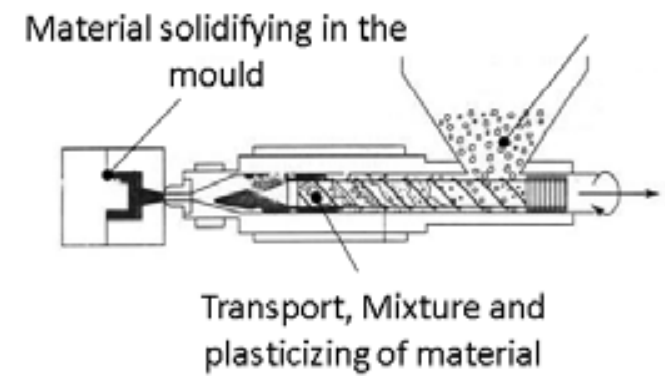

Figure 6. New step of the material plasticization 
5. Part extraction: material inside the mould continues cooling where the heat is dissipated for the cooling liquid. When cooling time is finished, the mould mobile part opens and the part is extracted (Fig.7).

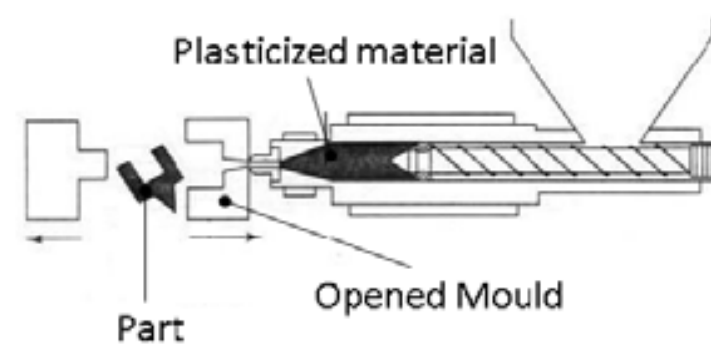

Figure 7. Part extraction

6. Close of the mould: Mould is closed and the injection moulding cycle restarts again.

By the powder injection moulding technology so called "green" part is obtained. This is a compact product and consists of the appropriate binder and powder.

For the purpose of this paper a material that consists of the thermoplastic binder and metal powder was chosen. A binder component is thermoplastic material polyacetal and metal powder component consists of the low alloy steel ingredients.

Polyacetals are known as semi-crystalline thermoplastics engineering polymers because they are used for the production of the stressed parts. A good overall property profile (good processing characteristics, high dimensional stability, high rigidity and good warm strength) makes polyacetals the preffered material in demanding applications. The advantage of this material in the moulding phase can, also, be utilized in the powder injection molding equally well $[12,13]$.

By the injection moulding of thermoplastic material (PPS) with powder additivies based on the metal element (Fe), transient element $(\mathrm{B})$ and rare earth element $(\mathrm{Nd})$, a "green" part which is used as a final product can be obtained. An example is the injection moulding of $\mathrm{NdFeB} / \mathrm{PPS}$ material and the production of so called plastic magnet [14].

\section{Debinding}

After the injection moulding phase and the production of a "green" part, next phase in the PIM technology is removing a binder component, shortly debinding or dispelling. By removing of the binder system a "brown (widely used term) or white part" is produced [15].

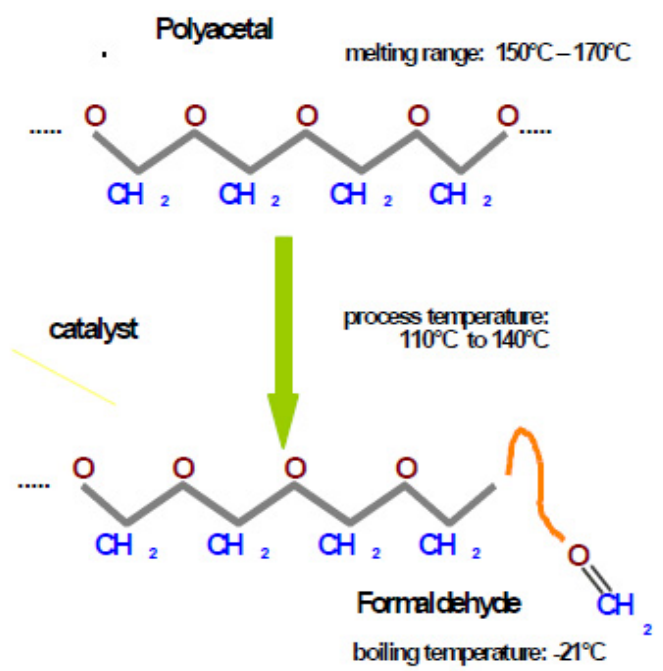

Figure 8. Chemical reaction of polyacetal removing from the "green" part
There are more ways of debinding process: thermal, by dissolving, catalytic, etc.

Thermal debinding is a process in which the binder is removed from a "green" part by thermal energy, often by burning.

Debinding by dissolving means that the appropriate chemical agents dissolve binder component.

Catalytic debinding process is based on an action of suitable catalyst on the binder component. Removing the mentioned component from the polyacetal/low alloy steel powder, the "green" part, is based on the ability of this material for catalytic gas phase decomposition of the binder. This ability is innate to the chemical structure of polyacetal chain which is characterized by the recurring carbon-oxygen bonds, as depicted in Figure 8 [13].

The oxygen atoms in the polymer chain is susceptible to the acid attack, causing the macromolecule split of successively $\mathrm{CH}_{2} \mathrm{O}$ (formaldehyde) unit when it is exposed to suitable acidic catalyst. The catalyst used for debinding process is gaseous nitric acid, in nitrogen atmosphere. The reason why this reaction is so eminently suited for debinding in the powder injection moulding are the conditions under which this reaction can take place. Debinding proceeds at a high speed at $110^{\circ} \mathrm{C}$, which is far below the melting range of polyacetal $\left(150^{\circ} \mathrm{C}\right.$ to $\left.170^{\circ} \mathrm{C}\right)$, so polymer is directy converted from solid into a gas. The binder-gas interface proceeds inward at the linear speed of $1 \mathrm{~mm} / \mathrm{h}$ to $2 \mathrm{~mm} / \mathrm{h}$. The small formaldehyde gas molecules (boiling point $-21^{\circ} \mathrm{C}$ ) are able to escape easily and without disruption the powder particle packing structure through the already porous outer zone of the part, as shown in Fig.9 [16].

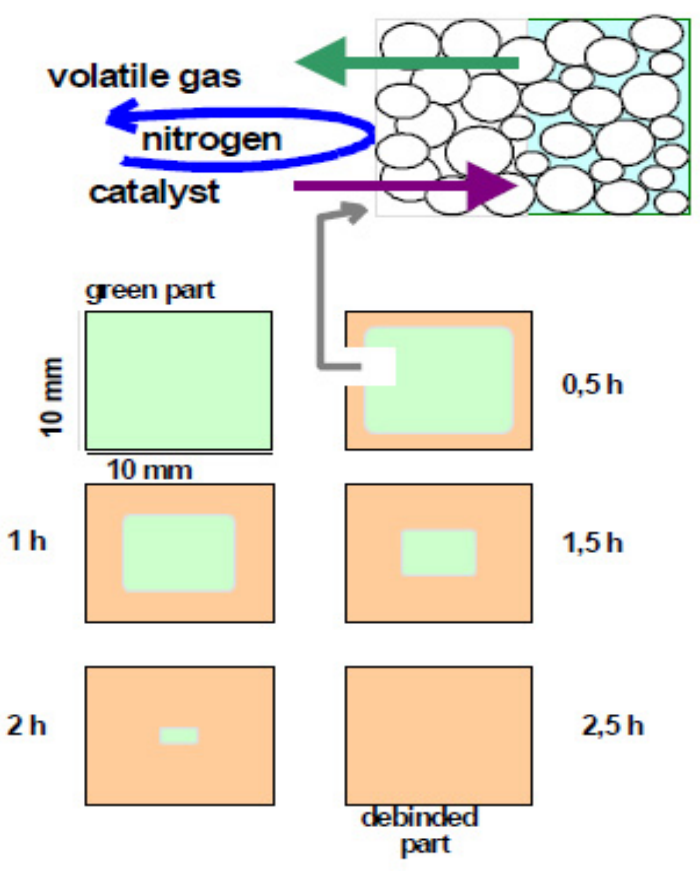

Figure 9. Polyacetal debinding mechanism from the "green" part

At the same time the binder is still fully rigid, lending the parts a continuing stiffness during debinding, avoiding any plastic deformation and resulting in better tolerances. After completion of polyacetal removing there is a residual amount (usually around 5 weight $\%$ to 10 weight $\%$ of the original binder content) of an acid resistance binder component, which confers a certain strength for handling to the part.

The catalytic debinding of the compact "green" part, which contains thermoplastic binder and metal powders, is done in a furnace, schematically presented in Fig. 10. 


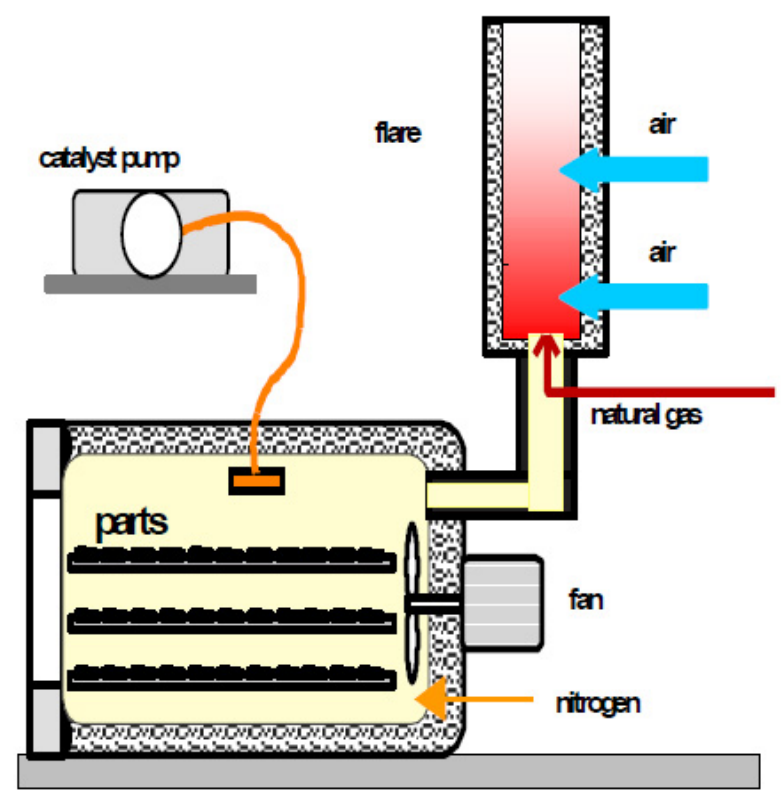

Figure 10. Scheme of removing and burning of the binder

During this catalytic reaction almost whole binder quantity is removed and a so called "brown" part, which contains binder in traces, is produced. The "brown" part has a porous structure and is very sensitive to the external mechanical actions.

Debinding phase ended by combustion of the present gaseous ingredients (formaldehyde gas, nitric acid gas, nitric oxides gas, etc.) to ecologically allowable products.

\section{Sintering}

During the sintering phase of the above mentioned "brown" part, two processes take place.

The first is removing, or more precisely spoken, thermal decomposition of the residual binder component.

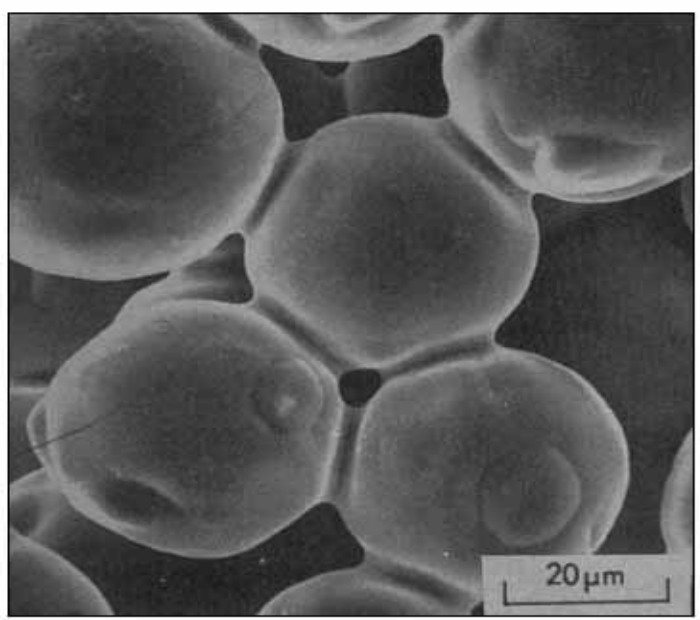

Figure 11. Growth of the particles contacts

The second process takes place in a porous part, which contains only metal powders. This process involves thermally activated transport of material on an atomic scale, resulting in a decrease in the specific surface area of the powder particles. The growth of the particles contacts and the reduction in the pore volume result, in macroscopic terms, in shrinkage of the part, is shown in Fig.11. The aim of sintering is to modify the properties of the article, which is highly porous in the debound state, towards the properties of a pore-free material. Parts are sintered under the protective gas atmosphere. The density achieved in finished parts is a measure of the sintering quality. The higher the density achieved, the better technological properties. Given appropriate process control, the density materials range from $96 \%$ to $100 \%$ of the theoretical values. The remaining pores are very small and uniformly distributed. Since they are virtually spherical, these pores are not responsible for crack initation [17].

The scheme of all four mentioned phases and corresponding products of the PIM technology, based on the thermoplastic binder and metal powder, is presented in Fig. 12 [16].

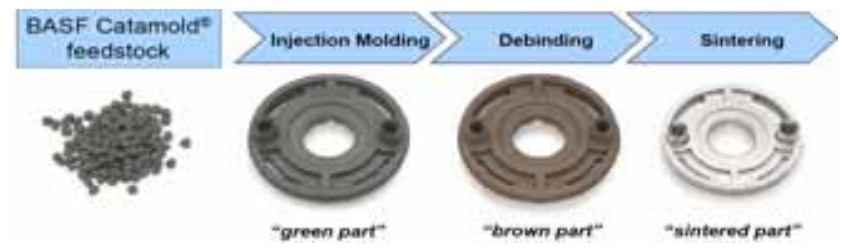

Figure 12. Scheme of the phases and corresponding products of the PIM technology

A catalytic debinding technology enables a fully continuous PIM process i.e. link between the highly automated moulding machines as used for plastic and the large throughput continuous sintering furnaces used in powder metallurgy, as shown in Fig.13 [17].

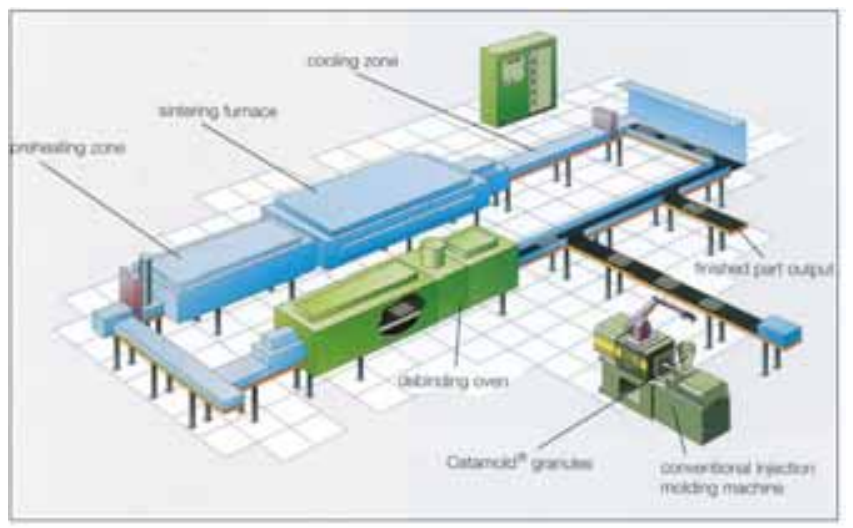

Figure 13. Continuous PIM process

There are several advantages of the PIM technology.

The first is the geometrical advantage because PIM offers several benefits in the component manufacturing. The most advantageous is its ability to mass produce net-shaped components that are geometrically complex. The process gives great versatility and freedom in the design of the advanced ceramic, metal, cermet and composite components. Designs previously rejected as too difficult or expensive to manufacture using other production techniques are made commercially possible. Features such as re-entrant angles, multi-shaped blind holes, screw threads, surface profiles, perpendicular holes, undercuts and intricate cavities are all possible using this technology.

The second advantage is concerning economy and scrap recycling. The prudent use of materials and equipment makes PIM very economical. Machining is eliminated or considerably reduced. In most of the various PIM processes, scrap produced in the form of feed systems, chippings or rejects can be recycled. This is particularly beneficial considering the high cost of some of the materials used. Another bonus is that cermets and ceramics, which are hard and difficult to process, are readily available as fine particulates at a reasonable cost, making them ideal for the PIM processing. Fine particles are necessary for achieving high sintered densities in the components. 
Another feature of the PIM process is the flexibility of the material composition. Intricately shaped components can be made with a wide range of consistent and reproducible densities. Components can be sintered specifically to create low density structures, which find use in the investment casting cores, insulation, filters, solid oxide fuel cells, substrates for catalysts and pre-forms for the manufacture of electronic packaging and lightweight structural ceramic/metal matrix composites. Blending two or more sinterable particulate systems enables complex components to be formed from novel alloy compositions, such as in situ metal matrix composites and aluminides [3].

Components obtained by the Powder Injection Technology find their place in many areas: in the automotive industry (combustion chambers, gear box parts, ignition lock parts, safety belt adjustment, reverse gear parts, pressure sensor fuel injector, latches, convertible roof, nozzles, locks, turbine wheel, gear), in the consumer products (hair trimmers, watch parts, precision parts for motors, knife blades, sports equipment, watch cases, household appliances, optical industry/glasses, harmonicas, scissors, spice mills), in the mechanical engineering (gear wheels, nozzles, locking systems, textile machinery parts, threaded inserts, pump rotors, handheld tools, hinges, levers, chip breakers/lathe tools, industrial machinery parts, thread guides, parts for sewing and knitting machines), in the communication/electronics (plugs, blocking device, socket, mobile phone shell, battery lock and hinge for mobile phones, ferrule for glass fiber connection, mobile phone pushbuttons, disc drive parts and hinges), in medical technology (laparoscope parts, orthodontic parts, surgical instruments, glucose watch, scalpel, insulin pump parts, coloscope parts, pump casing, endoscope parts, tweezers, dental instruments) [18].

The inherent hardness of ceramics means that manufacturing intricately shaped ceramic components by standard machining processes is very expensive. Prior to PIM, intricately shaped ceramics had a limited market and were only used as a last resort in applications that required their specific properties. Applying the PIM technology to the advanced ceramics has broadened the use of these materials [3].

For cost reasons, up to few years ago, there were upper weight limit roughly $200 \mathrm{~g}$, upper wall limit to $10 \mathrm{~mm}$ and the longest part encoutered is $200 \mathrm{~mm}$ [17].

These limits are overcame and now are produced a large and complex product like a 1,6 kg jet-airplane flow-body housing (Fig.14) and a small and precision part, such as a toothed wheel for the watch industry (Fig.15) [19,20].
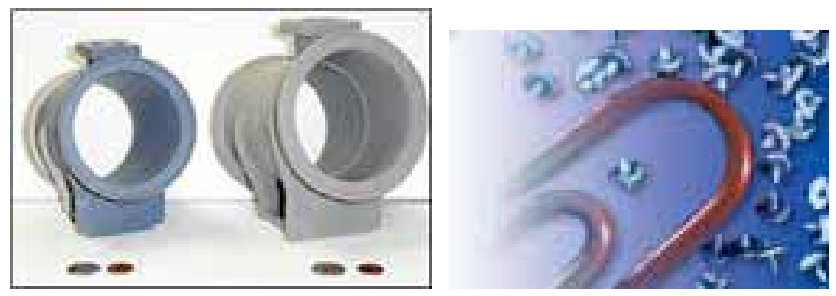

Figure 14. Jet-airplane flow-body Figure 15. Toothed wheel (Final housing (Green part is at right, shape)

sintered result at left)

Products, obtained by the PIM technology are used in firearms and defence systems.

Figure 16 shows a MIM titanium trigger produced for an Italian gun manufacturer.

Because of the high material costs, the MIM titanium components are currently limited to high performance applications (in terms of fatigue properties, biocompatibility, and light weight), or luxury consumer products where titanium adds exclusivity and marketability.

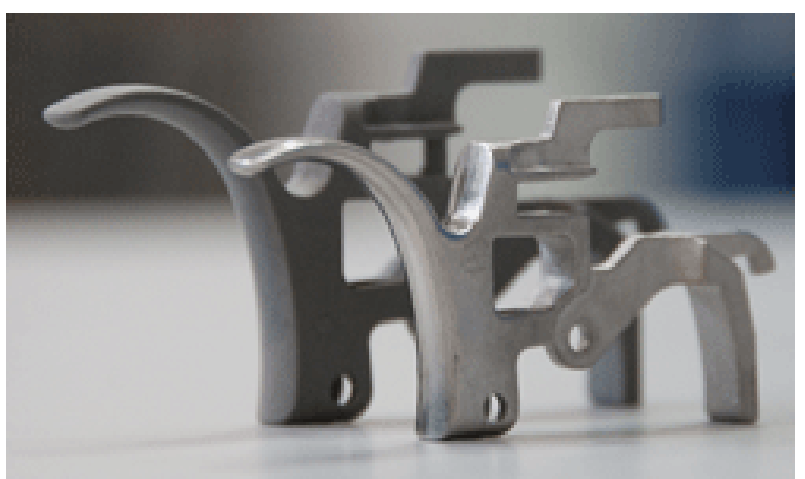

Figure 16. MIM titanium gun trigger (in the background is the "green part" and in the foreground the sintered part)

The military "safe and arm" rotor shown in Fig. 17 is used in an explosive device for the US Department of Defense application.

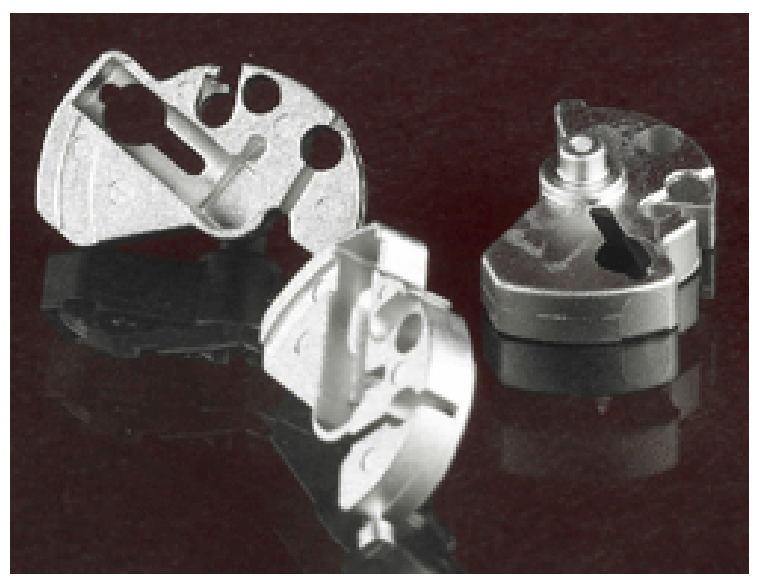

Figure 17. Safe and arm rotor

The complex shape features numerous outside radii and angular surfaces. At least 12 functional features and surfaces are geometrically controlled by concentricity, profile, and true position tolerances.

The part is assembled into a housing to provide the twostage safety for the explosive device. It replaced a zinc die casting whose mechanical properties were ultimately not consistent enough to pass validation testing.

This pistol safety part (Fig.18) is used in the 1911-style 45caliber pistol. The upswept design of the grip safety part, which was traditionally investment cast, would previously require an extensive secondary machining. Switching to the MIM process reduced customer lead times and provided exceptional cost savings, in addition to increasing production rates and producing a more uniform part.

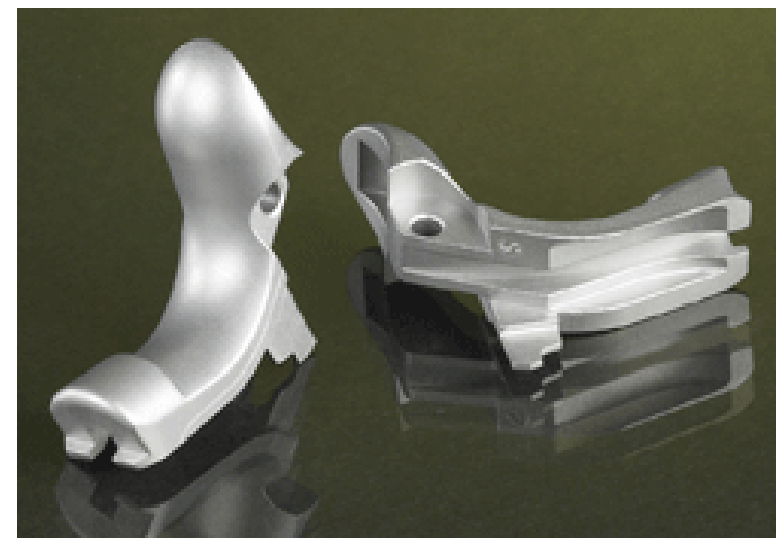

Figure 18. Pistol upswept grip safety part 
The part performs several functions: it blocks the trigger from firing, shields the hammer from impacting or injuring the shooter's hand when the pistol cycles, and interacts with the shooter's palm for comfort [21].

\section{Experimental part}

One of the most significant group of the MIM products are ferrous parts (low alloy steel, stainless steel, tool steel, etc.) [8].

For the purpose of this paper a low alloy steel PIM material of Catamold 4605 trade name, produced by the Chemical Company BASF, Ludwigshafen, was chosen. This PIM material is classified as a low alloy steel and contains a polyacetal as thermoplastic binder and in ferrous based metal powder there are carbon (from $0,4 \%$ mass to $0,6 \%$ mass), nickel (from $1,5 \%$ mass to $2,5 \%$ mass), molybdenum (from $0,2 \%$ mass to $0,5 \%$ mass) and silicon (less than $1 \%$ mass) [18].

A standard test specimen according to the ASTM E8/E8M11 is chosen as a product of the first phase of the mentioned technology, i.e. of the injection moulding. The chosen test specimen is shown in Figure 19 [22]. The choice is based on the fact that the final product of the multi-phase PIM technology is a compact part of completely metal structure.

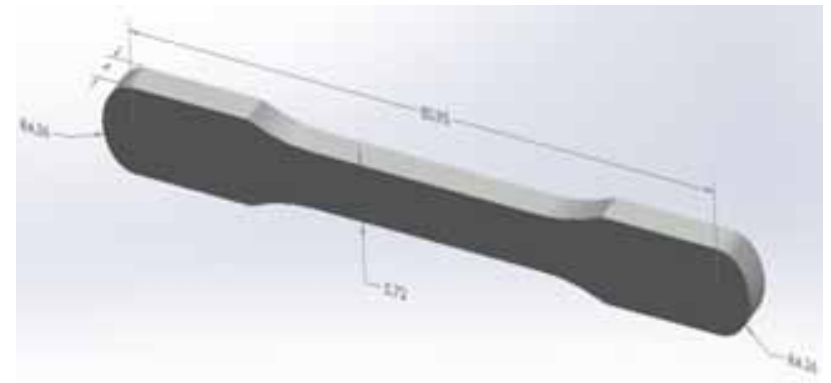

Figure 19. Test specimen according to the ASTM E8/E8M-11 standard

Concerning the injection moulding of the mentioned feedstock, it is important to point out, that due to the crystallinity of the polyacetal based binder, but also due to the much higher thermal conductivity of the used material, the mould temperature is an uncharacteristically high $\left(120^{\circ} \mathrm{C}\right)$, regarding comparatively low cylinder temperature (from $160^{\circ} \mathrm{C}$ to $\left.190^{\circ} \mathrm{C}\right)[13]$.

\section{Results of testing and analysis}

Determination of the original feedstock characteristics and an injection moulded specimen properties were done.

A visual appearance, density, metal powder content and a structure of feedstock were tested.

The following properties of the injection moulded specimen, i.e. "green" part, were determined: visual appearance, density, mass, metal powder content and structure.

A visual appearance of the feedstock and of the "green" part was tested by a naked eye, without any magnifying instrument.

Density of the feedstock was examined by pycnometer method and density of the "green" part was tested by the immersion method, both according to the SRPS EN ISO 1183-1 [23].

A metal powder content and a structure of feedstock and metal powder content and structure of the injection moulded specimen were determined by a semi-quantitative method using the Scanning Electron Microscope model JSN-6610LV, manufactured by JEOL, equipped with the Energy Dispersive Spectrometer, produced by the OXFORD Instruments.
Mass of the injection moulded specimen was determined by the technical balance.

\section{Results of the feedstock testing}

Density of the used feedstock is $4,53 \mathrm{~g} / \mathrm{cm}^{3}$.

Visual appearance of grey-bluish granulates of the Catamold 4605 trade mark feedstock is shown in Fig.20.

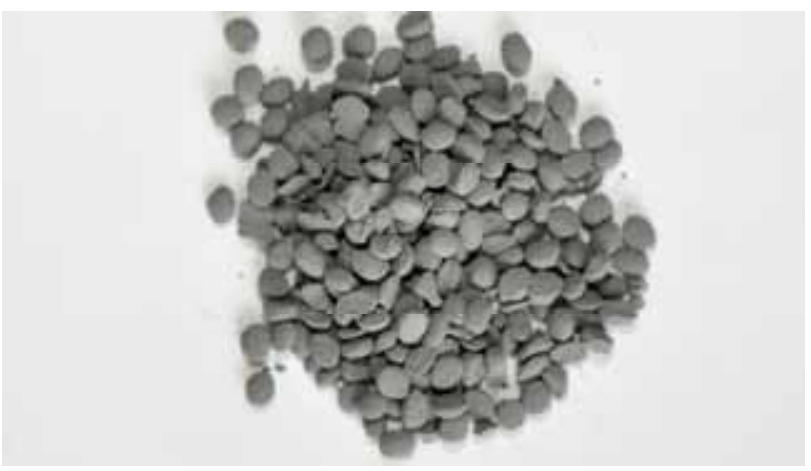

Figure 20. Visual appearance of the Catamold 4605 granule feedstock

Laboratory (lab) determined metal powder content of the feedstock, i.e. Catamold 4605, and the content of the same metal elements according to the ASTM B 883-10 are presented in Table 1 [24].

Table 1. Metal powder content of the feedstock and according to the ASTM B 883-10

\begin{tabular}{||c|c|c||}
\hline \hline Metal element & $\begin{array}{c}\text { Content to lab tests } \\
\text { (\% mass) }\end{array}$ & $\begin{array}{c}\text { Content to ASTM 883-10 } \\
\text { (\% mass) }\end{array}$ \\
\hline \hline Nickel & 1,62 & from $1,5 \%$ to $2,5 \%$ \\
\hline Molybdenum & 0,29 & from $0,2 \%$ to $0,5 \%$ \\
\hline Silicon & 0,45 & less than $1 \%$ \\
\hline Carbon & $0,5^{*}$ & from $0,4 \%$ to $0,6 \%$ \\
\hline Ferrum & 97,14 & Balance \\
\hline
\end{tabular}

* estimated value

As can be seen from Table 1, there is a good agreement between laboratory determined metal powder content and requirements from the ASTM B 883-10.

Scanning electron micrograph of feedstock, i.e. Catamold 4605, is presented in Fig.21.

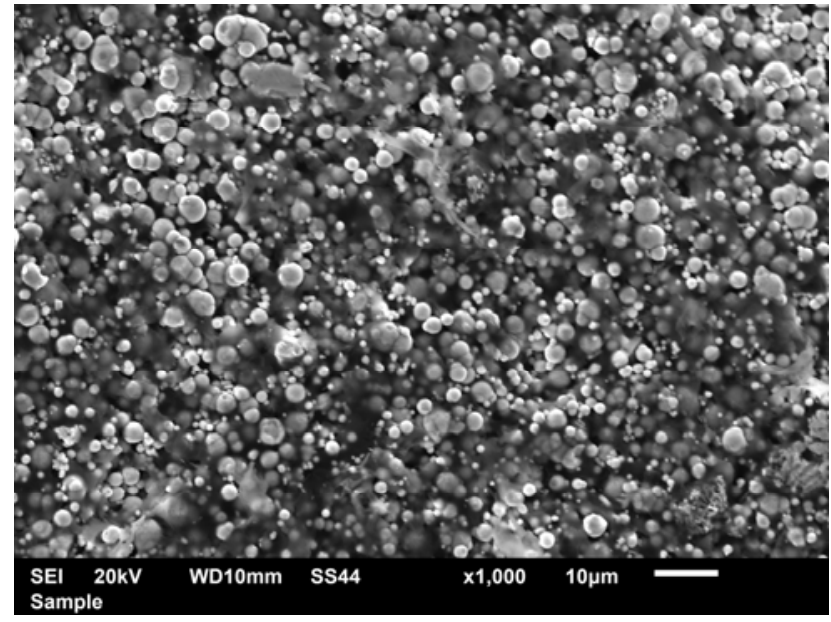

Figure 21. Scanning electron micrograph of the Catamold 4605 granule feedstock

\section{Results of the injection moulded specimen testing}

Injection moulded specimen has a flat and shine outer area without scretches and visual defects, as can be seen in Fig.22. By the visual inspection of the injection moulded specimen 
("green" part) neither leaking nor overheating were not recorded.

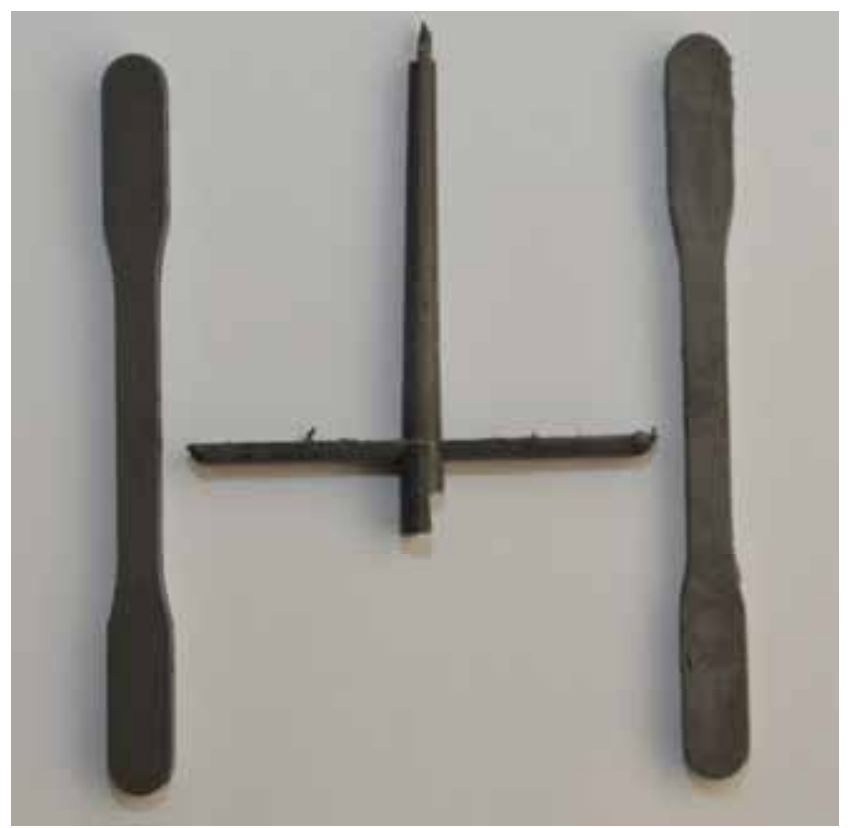

Figure 22. Complete injection moulded specimen

Density of the injection moulded specimen is $4,63 \mathrm{~g} / \mathrm{cm}^{3}$.

Laboratory determined metal powder content of the feedstock and injection moulded specimen is presented in Table 2.

Table 2. Metal powder content of the feedstock and injection moulded specimen

\begin{tabular}{|c|c|c|}
\hline Metal element & $\begin{array}{c}\text { Feedstock } \\
\text { (\% mass) }\end{array}$ & $\begin{array}{c}\text { Injection moulded specimen } \\
\text { (\% mass) }\end{array}$ \\
\hline \hline Nickel & 1,62 & 1,65 \\
\hline Molybdenum & 0,29 & 0,30 \\
\hline Silicon & 0,45 & 0,49 \\
\hline Carbon & $0,5^{*}$ & $0,50 *$ \\
\hline Ferrum & 97,14 & 97,06 \\
\hline
\end{tabular}

* estimated value

Mass of the complete injection moulded specimen is determined and the single test values $(X)$, arithmetic mean values $(\bar{X})$ and standard deviations values $(\sigma)$ are presented in Table 3.

Table 3. Mass of the complete injection moulded specimen

\begin{tabular}{|c|c||}
\hline \multicolumn{2}{|c||}{$\begin{array}{l}\text { Mass of the complete } \\
\text { injection moulded specimen, } \mathrm{g}\end{array}$} \\
\hline$(X)$ & $\bar{X} \pm \sigma$ \\
\hline 27,$97 ;$ & \\
27,$12 ;$ & \\
28,$42 ;$ & $27,71 \pm 0,51$ \\
27,$85 ;$ & \\
28,$12 ;$ & \\
27,$13 ;$ & \\
27,41 & \\
\hline
\end{tabular}

As can be seen from Table 3, laboratory determined values of the injection moulded specimen mass are uniform, which indicates that injection moulding process was realised correctly.

Scanning electron micrograph of the injection moulded specimen is presented in Fig. 23.

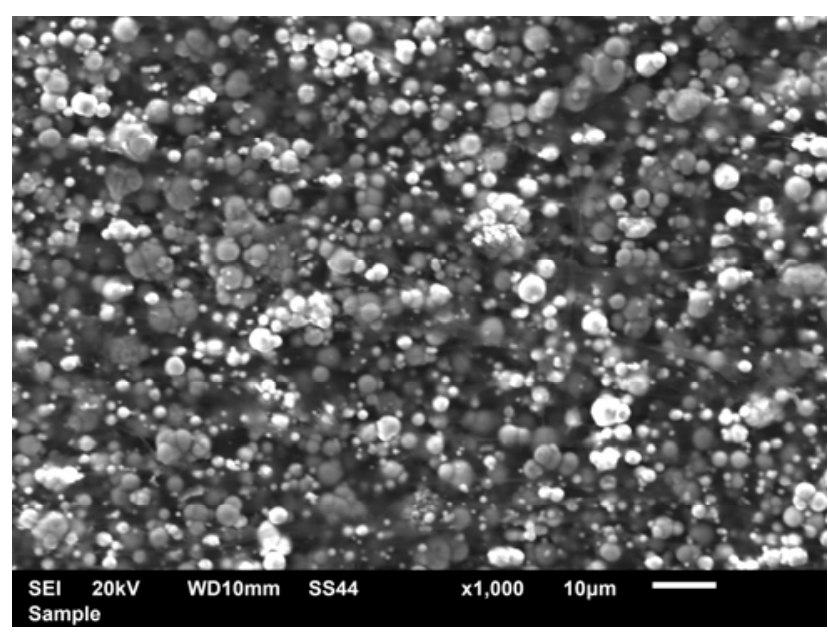

Figure 23. Scanning electron micrograph of the injection moulded specimen

By analyzing the scanning electron micrograph of the feedstock (Fig.21) and scanning electron micrograph of the injection moulded specimen (Fig.23) it can be seen that there are slight differences in structures, which is another indication that the injection moulding process was realised correctly.

\section{Conclusions}

From the previous text it can be concluded:

1. Powder Injection Moulding is a multi-phase technology which enables a high-volume production of completely metal or ceramic complex geometry parts starting from non-completely metallic and ceramic materials, frequently plastic feedstock.

2. An injecion moulding of thermoplastic polyacetal binder/metal low alloy steel powder material was done and injection moulded product ("green" part) was obtained for the first time in Serbia.

3. Fabrication of the injection molded product represents an important step of the powder injection molding technology.

4. Properties of the used polyacetal/low alloy steel feedstock and injection moulded product ("green" part) are tested.

5. Feedstock metal content is in accordance with the demands specified in the standard for metal injection moulding ferrous materials.

6. The tested characteristics of the injection moulded product ("green" part) indicate that the injection moulding process was done correctly and degradation of the used feedstock did not happen.

\section{Literature}

[1] RADULOVIĆ, J.: Influence of Internal Cyclic Pressure on Filamentwound Composite Tubes Quality, Scientific Technical Review, ISSN 1820-0206, 2010, Vol.60, No.1, pp. 54-60

[2] RADULOVIC, J.: Injection moulding: essential step of powder injection moulding (PIM) technology, 6th International Scientific Conference on Defensive Technologies OTEH 2014, 09-10. October 2014, Belgrade, SERBIA, Proceedings, ISBN 978-86-81123-71-3, pp.790-795

[3] MICHAEL, M.: Materials World, February 1999, Vol.7, No.2, pp.7175 .

[4] WILliAMS, B.: Parmatech Shapes Metals like Plastics, Metal Powder Report, 1989, Vol.44 No.10, pp.675-680.

[5] US patent number 4197118, Manufacture of Parts for Particulate material, Apr 8, 1980. 
[6] www.pim-international.com/aboutpim/mim_materials

[7] BERGINC,B., ROT,M.: Brizganje prašnatih materijalov, IRT 3000, June 2007, No.9, pp.139-141,

[8] ZLATKOV,B.S. et al.: Recent Advances in PIM Technology I, Science of Sintering, 2008, Vol. 40, pp.79-88

[9] GOODSHIP,V.: Arburg, Practical Guide to Injection Moulding, iSmithers Rapra Publishing, 2004, ISBN 1859574440.

[10] MUENK,A.: New Catamold ® product line for metal injection molding, April 22 2013, P 246/13e, www.basf.com.

[11] BARANDA,ENRIQUEZ, MA.: Design and manufacturing of complex moulds for powder injection moulding, Master Project, Universidad Carlos III de Madrid, Hes so Valais Wallis University of Applied Science, Western Switzerland, February 2010.

[12] RADULOVIĆ,J.: Investigation of the influence of natural weathering factors on the properties of polyamide thermoplastic materials, Scientific Technical Review, ISSN 1820-0206, 2005, Vol. LV, No.3-4, pp.21-28.

[13] Catamold Feedstock for Metal Injection Moulding, Technical Information: Processing - Properties -Applications, BASF AG, 2003.

[14] www.bvmagnetics.manufacturer.globalsources.com/si/6008846357682 /pdtl/Rare-earth-magnet/1061555592/NdFeB-Magnet.htm.

[15] www.wittmann-group.com/injection-molding/processtechnology/powder-injection-molding-pim

[16] Catamold Feedstock for Metal Injection Molding, T Catamold 4605, Data Sheet, BASF, The Chemical Company, Ludwigshafen, April, 2006.
[17] MAAT, J., THOM, A., BLOEMACHER, M.: Metal Injection Moulding-Steel Component made easy with Plastic Processing Technology, Technical Information, BASF, Aktiengesellschaft, Ludvigshafen, Germany.

[18] Sales+Products+Catamold+Ti-Brochure Catamold+Imagination+is+the+only+Limit-English.pdf.

[19] KNIGHTS, M.,: 'Home Articles" Metal-Powder Injection Molding Moves Into Larger Parts, Plastics Technology, February, 2003.

[20] ROWNTREE,A.: Powder Injection Moulding, Published by International Specialised Skills Institute, Melbourne, 2007.

[21] Applications for MIM VI: Firearms and Defence (C PIM International Inovar Communications Ltd, 2 The Rural Enterprise Centre, Battlefield Enterprise Park, Shrewsbury SY1 3FE, UK, Email: info@ipmd.net.

[22] ASTM E8/E8M-11 Standard Test Method for Tension Testing of Metallic Material, ASTM Committee of Standards, Philadelphia, 2011.

[23] SRPS EN ISO 1183-1 Plastics-Methods for determining the density of non-cellular plastics-Part 1: Immersion method, liquid pycnometer method and titration method, Institute for Standardization of Serbia, Belgrade, 2013.

[24] ASTM B 883-10 Standard Specification for Metal Injection Moulding (MIM) Ferrous Materials, ASTM Committee of Standards, Philadelphia, 2010.

\title{
Tehnologija injekcionog presovanja prahova: karakteristike, mogućnosti i početne aktivnosti
}

\begin{abstract}
Tehnologija injekcionog presovanja prahova (skraćeno PIM) omogućava velikoserijsku proizvodnju potpuno metalnih ili keramičkih delova složene geometrije polazeći od materijala, koji nisu u potpunosti metalni ili keramički, već uglavnom plastični.

Opisane su četiri faze PIM tehnologije (umešavanje polaznog materijala, injekciono presovanje materijala plastično vezivo/metalni prah, uklanjanje vezivne komponente i sinterovanje) polazeći od materijala koji se sastoji od plastičnog veziva i metalnih prahova. Izabran je polazni materijal poliacetalno vezivo/prahovi nisko legiranog čelika i tehnologijom injekcionog presovanja urađen je otpresak tzv. ,zeleni komad“( (preciznije rečeno ispitna epruveta prema standardu ASTM E8/E8M-11), po prvi put u Srbiji. Ispitane su karakteristike polaznog materijala (gustina, semi-kvantitativna analiza, vizuelni izgled) i osobine „zelenog komada“ (masa, gustina, semi-kvantitativna analiza, vizuelni izgled). Zaključeno je da su dobijeni zadovoljavajući rezultati.
\end{abstract}

Ključne reči: injekciono presovanje, presovanje praha, tehnološka poboljšanja, karakteristike procesa.

\section{Технология порохового литья под давлением: особенности, возможности и начинающиеся активности}

\begin{abstract}
Технология порохового литья под давлением (сокращенно ПИМ) обеспечивает высокое серийное производство полностью металлических или керамических частей сложной геометрии, начиная с материалов, которые не в полной мере металлические или керамические, но в основном пластические.

Здесь описаны четыре этапа ПИМ технологии (смешивание исходного материала, литье под давлением материалов соединительная пластмасса / металлический порошок, удаление связующей компоненты и спекание) исходя от материала, состоящего из пластиковой связующей компоненты и металлического порошка. Был избран исходный материал в качестве полиацетальной связующей компоненты / порошки низколегированной стали и технологией литья под давлением изготовлен впрыск так называемый "Зелёный кусок" (точнее сказано испитываемый образец труба в соответствии со стандартом ASTM E8 / E8M-11) впервые в Сербии. Рассмотрены характеристики исходного материала (плотность, полуколичественный анализ, внешний вид) и свойства «зелёных кусков" (масса, плотность, полуколичественный анализ, внешний вид) и был сделан вывод, что были получены удовлетворительные результаты.
\end{abstract}

Ключевые слова: пороховое литье под давлением, литье порошка, технологические усовершенствования, характеристики процесса. 


\title{
Technologie du pressage d'injection des poudres: propriétés, possibilités et activités initiales
}

\begin{abstract}
La technologie du pressage d'injection des poudres (PIM en abrégé) permet une grande production sérielle des parts en métal ou en céramique de géométrie complexe en partant des matériaux qui ne sont pas entièrement en métal ou en céramique mais principalement en plastique. On a décrit quatre phases de la technologie PIM ( malaxage de matériau de départ, pressage d'injection du matériau liant plastique / poudre en métal,élimination de la composante liante et frittage) à partir du matériau composé du liant plastique et des poudres en métal. Pour matière de départ on a choisi le liant poly acétal / poudre de l'acier faiblement allié et par la technologie de pressage d'injection on a fait un produit de moulage nommé «part verte» ( plus précisément éprouvette produite selon la norme ASTM E8/E8M-11) pour la première fois en Serbie. On a examiné les caractéristiques de la matière de départ (épaisseur, analyse semi quantitative, aspect visuel) ainsi que les propriétés de « la part verte" (masse, épaisseur, analyse semi quantitative, aspect visuel). On a conclu que les résultats obtenus étaient satisfaisants.
\end{abstract}

Mots clés: pressage d'injection, pressage des poudres, perfections techniques, caractéristiques du processus. 